\title{
Assessment of lake sediments properties and contaminations level
}

\begin{abstract}
Sediments are principal carriers of the trace elements in the hydrosphere. Properties of the sediment (such as grain size, specific surface area and pore volume) decide the concentration level of the pollutant contain in water. The properties of sediment differed in each lake according to the normal geological phenomenon and source of discharge wastewater. The purpose of this study is to investigate the properties and contamination level of the sediment collected from lakes in Universiti Putra Malaysia (UPM). Sediment samples are taken from three different lakes; Lake IT, Lake ENG and Lake PK. These locations are selected due to the type of wastewater has been discharged into the lakes which are from colleges and academic buildings. The sediments were tested in terms of physical, chemical properties and contaminant concentration $(\mathrm{Pb}, \mathrm{P}$ and $\mathrm{Cu})$. Using the contaminant concentration results; the sediment concentration level of the pollutant of each lakes were referred to the ConsensusBased Sediment Quality Guidelines (CBSQG-2003). The dominant grain sizes of the sediments were found in the range of silt/clay; with the size fraction in the range $12.74 \%$ to $12.83 \%$. The specific surface areas of sediments were in the range of 16.3 to $22.5 \mathrm{~m} 2 / \mathrm{g}$ with a pore size distribution in the range of 20 to $29 \mathrm{~mm} 3 / \mathrm{g}$. The chemical properties show that the $\mathrm{pH}$ values are in normal range; $\mathrm{pH} 7$, TOC values in the range of 10.84 to $12.39 \%$ and salinity values in the range of 0.05 to $0.06 \mathrm{dS} / \mathrm{m}$. The contaminant concentrations show that the main heavy metal presents in Lake IT, Lake ENG and Lake PK as Lead $(\mathrm{Pb})$ with 0.033 $\mathrm{mg} / \mathrm{l}, 0.036 \mathrm{mg} / \mathrm{L}$ and $0.038 \mathrm{mg} / \mathrm{L}$, respectively. According to the CBSQG-2003, due to the concentration of Lead presents in lakes sediment in UPM area, the sediments were categorised as non-polluted.
\end{abstract}

Keyword: Chemical properties; Heavy metal; Lake sediments; Lead; Physical properties 